\title{
Helicobacter pylori and Peptic Ulcer - Role of Reactive Oxygen Species and Apoptosis
}

\author{
Trinidad Parra-Cid1,3, Miryam Calvino-Fernández ${ }^{1,3}$ \\ and Javier P. Gisbert 2,3 \\ ${ }^{1}$ Unidad de Investigación. Hospital Universitario de Guadalajara \\ ${ }^{2}$ Servicio de Aparato Digestivo. Hospital Universitario de La Princesa \\ e Instituto de Investigación Sanitaria Princesa (IP)(Madrid) \\ ${ }^{3}$ CIBERehd (Centro de Investigación Biomédica en Red, \\ Enfermedades Hepáticas y Digestivas)
}

Spain

\section{Introduction}

Peptic ulcers and gastritis are a serious and growing health problem in the whole world. Ulcers affect about 5 million Americans each year, and more than 40,000 people annually have ulcer-related surgery. Each year, approximately 15,000 people in the Unites States die of ulcer-related complications, the worst of which are an internal bleeding and perforation.

A peptic ulcer is an open sore or lesion in the gastrointestinal mucosa (stomach or duodenum) that extends through the muscularis mucosa. Peptic ulcers occur when the mucous lining of the stomach or duodenum is not sufficient to protect them against the corrosive action of stomach hydrochloric acid, pepsin digestive enzyme, or against other aggressive substances. These aggressive factors can have an endogenous or exogenous origin. The endogenous harmful factors apart from hydrochloric acid and pepsin, are: refluxed bile, leukotrienes and Reactive Oxygen Species (ROS). The exogenous damaging factors include lifestyle factors, such as alcohol abuse, stress, tension and smoking; also, consume of steroidal and nonesteroidal anti-inflammatory drugs (NSAIDs) or drugs which stimulate gastric acid and pepsin secretion. Moreover, it is completely accepted that the bacterium called Helicobacter pylori (H. pylori) is implicated in the development of gastric ulcers and gastritis.

However, many researchers suggest that both the presence of $H$. pylori and the circumstances related to lifestyle and the consumption of certain drugs are risk factors to develop ulcer, but not the underlying causes, consequently, they add severity to the problem but are not able to cause it. Although these factors are almost certainly of pathogenic relevance, there are majority of people with exposure to them who remain ulcerfree and only a small number of them develop ulcers. In fact, considering the acid-peptic environment of the stomach, the noxious agents both the endogenous and the exogenous that are ingested, and the high prevalence of $H$. pylori infection, ulcers are surprisingly uncommon.

To explain this, it is thought that in gastric mucosa is established a balance between these aggressive factors and other cytoprotective factors, and that gastric ulcer appears when the 
balance is lost. The mucosal defense is constituted by mucus-bicarbonate barrier, surface active phospholipid, prostaglandin, mucosal blood flow, cell renewal and migration, antioxidants and antioxidant enzymes, and some growth factors.

\section{Free radicals and antioxidant defences}

Gastroduodenal disease is associated with a variety of risk factors, including tobacco smoke, hereditary influences, sex, diet, stress and the actions of drugs (NSAIDs) (Marotta \& Floch, 1991; Wallace, 1992). There is evidence that free radicals and antioxidants may be important components in the pathophysiology of gastroduodenal disease caused by many of these factors, implicating $H$. pylori. Free radicals have been involved in a wide spectrum of human diseases including other digestive disorders such as inflammatory bowel, toxic liver injury or pancreatic disease (Phull et al., 1995).

ROS can be defined as any chemical species capable of independent existence that contain one or more unpaired electrons in their outer orbital. Considering that the most stable molecular species have the electrons within their outer orbital arranged in pairs, free radicals tend to be unstable and highly reactive.

Oxygen is the most abundant radical in biological systems. The seemingly paradoxical consequences of the beneficial and harmful effects of oxygen $\left(\mathrm{O}_{2}\right)$ have been shown for several decades. While more than $95 \%$ of the $\mathrm{O}_{2}$ consumed by the aerobic organisms is fully reduced to water during the process of mitochondrial respiration, a small percentage $(<5 \%)$ is converted to semireduced species such as superoxide anion radical $\left(\mathrm{O}_{2}-{ }^{-}\right)$, hydrogen peroxide $\left(\mathrm{H}_{2} \mathrm{O}_{2}\right)$ and hydroxyl radical $(\mathrm{OH} \cdot)$. These species are collectively named "Reactive Oxygen Species or ROS". ROS are formed continuously as normal byproducts of cellular metabolism and several of their sources are mitochondrial oxidative phosphorylation, prostaglandin synthesis, non-mitochondrial respiratory burst of neutrophils, and possibly the inhibition of mitochondrial electron transport.

Antioxidant defences: Free radicals play a number of physiological roles, but due to their high reactivity tend to attack the first biochemical component that they encounter inside cells, including macromolecules such as lipids, proteins or nucleic acids and bring about oxidative damage (Reilly et al., 1991). To avoid the oxidative damage, cells have development defence mechanisms to limit or prevent the toxicity caused by an excessive ROS activity. These defenses include non-enzymatic compounds such as vitamin (Vit) A, E and $\mathrm{C}$, and enzymatic substances such as superoxide dismutase, catalase, glutathione peroxidase, and glutathione S-transferase; the latter two enzymes using glutathione (GSH) as a cofactor. Tissue damage may result from excessive ROS activity, from any deficiency in the defence mechanisms or from both of them.

It is well known that low/moderate concentrations of ROS affect a great number of physiological functions. However, when ROS concentration exceeds the antioxidative capacity of an organism, cells enter a state termed oxidative stress, in which the excess ROS induces oxidative damage on cellular components. So, ROS have been implicated in the pathogenesis of many human sufferings like Parkinson's, Alzheimer, Huntington's diseases and many other neurodegenerative conditions (Halliwell B, 1989). There is ample evidence that free radicals and antioxidants may be important components in the pathophysiology of gastroduodenal disease, in fact, as noted above, an exacerbated synthesis of free radicals has been implicated in inflammatory bowel disease, toxic liver injury or pancreatic disorders. 


\section{Free radicals, antioxidant defences and gastroduodenal diseases}

A growing body of experimental and clinical evidence suggests that gastric mucosal damage by ethanol, NSAIDs and by H. pylori (Davies et al., 1994) is mediated through ROS (Phull et al., 1995). The cause could be the excessive synthesis, the deficiency of antioxidants defences or the coexistence of both reasons.

Most of the studies in this area have focused on the link between low intakes of fresh fruit and/or vegetables and gastric cancer. Several data show that exist an increased risk of gastric cancer specifically related to low intakes of Vit $C$ and $\beta$-carotene or that $\beta$-carotene and Vit E levels were significantly lower in subjects with gastric dysplasia, a precursor of gastric cancer (Haenszel et al., 1985). Lower plasma levels of Vit A, C and E in subjects with chronic atrophic gastritis (Jaskiewicz et al., 1990) has been detected in a cross-sectional and prospectives studies showing that an increased risk of gastric cancer is associated with low plasma $\alpha$-tocoferol (Knekt et al., 1991), Vit C, $\beta$-carotene (Stahelin et al., 1991), retinal levels and with low selenium levels (van den Brandt et al., 1993). Respect to the selenium, some evidence suggest that the diet of dyspeptic patients is deficient in the micronutrient selenium, which is an important constituent of the antioxidant enzyme glutathione peroxidase (GSH-Px).

Involvement of ROS in the pathogenesis of gastric ulceration was first evident from the studies of ischemia-reoxygenation-induced gastric mucosal injury. Many of the works in this area have been performed by Davies et al using a chemiluminiscence assay (Davies et al., 1994). They have shown significantly greater free radical production in duodenal mucosal biopsies from patients with duodenal ulceration and severe duodenitis that in patients with mild duodenitis or controls. This increased free radical activity in duodenal ulcer patients is accompanied by reduced levels of plasma glutathione (GSH). Recent studies show the same conclusions: there is an increased ROS production in gastric ulceration compared with gastric antral mucosa (Peng et al., 2008). Gastric ulceration also appears to be associated with increased plasma free radical activity and lower levels of Vit $C$ and $E$, but not with superoxide dismutase (SOD) or catalase. ROS also decrease the level of endogenous antioxidants such as GSH, $\alpha$-tocopherol and ascorbate, and make the mucosa more prone to oxidative damage.

Moreover, ROS may play an important role in gastric ulceration induced by several kinds of stress. The pathogenesis of gastric mucosal lesions by water immersion restraint stress and burn shock in rat is associated with increased lipid peroxidation. Furthermore, cold restraint stress has been shown to alter the level of various damaging and cytoprotective factors of rat gastric mucosa to cause gastric ulceration (Das et al., 1997). It was reported (Yoshikawa et al., 1989) that the gastric mucosal injury induced by ischemia-reperfusion is avoided after administration of SOD and catalase, indicating the role of lipid peroxidation and ROS in the origin of the lesion. Similarly, astaxanthin has been shown to provide protection against naproxen-induced and stress-induced gastric ulceration by reducing the level of lipid peroxides and free radicals indicating again the role of ROS in gastric damage (Oh et al., 2005). The inhibitory effect of diacerein on indomethacin-induced gastric ulceration by inhibition of neutrophil activation (Tamura et al., 2001), and consequently the suppression of ROS production by these cells, leads to similar conclusions.

Furthermore, Davies et al. (Davies et al., 1994) also detected higher levels of ROS in antral mucosa infected with $H$. pylori and they affirmed that there is no evidence for ROS participation in gastric mucosal injury in cases not related to $H$. pylori infection. Other works 
show that ROS levels are directly correlated with the infective load of H. pylori (Zhang et al., 2007) and lipid peroxidation has been also shown to be increased in H. pylori-positive gastric mucosa.

But although it has been established a clear association between bacteria infection and impaired synthesis of ROS, many other clinical data suggest that other factors inherent to host conditions (stress, diet, tobacco, hygiene, genetics...) contribute to the pathogenesis of this infection (Oh et al., 2005). It should be noted that some of these factors, including ingested food and tobacco smoke, directly influence in mucosal oxidative status, since they expose the gastric epithelium to the ROS that they generate within the gastric lumen in a sustained manner.

\section{Helicobacter pylori and gastroduodenal diseases}

\subsection{Short history}

The evolution over time of the peptic ulcer epidemiology reflects a complex and multifactorial etiology. Peptic ulcers were rare before 1800, so the gastric ulcer pathology was not described until 1835 (J. 1835 Cruveilhier maladies de l'estomac In Anatomy of Human Bailliere Pathologique du Corps, Paris ...). During the nineteenth century, the predominant form was gastric ulcer in young women, while duodenal ulcer was rare until the twentieth century. However, duodenal ulcer was gradually more prevalent until become the more frequent condition in the middle of the century. Moreover, in developed countries the mortality from peptic ulcer has been drastically reduced for the cohorts born after the start of the twentieth century (Sonnenberg, 2007).

It is now clear that the epidemiology of the peptic ulcer is mainly due to external environmental factors, among which are include H. pylori infection, the use of NSAIDs and smoking. However, these factors do not explain the whole story of the evolution in time and the birth-cohort effect for peptic ulcer. Specifically, H. pylori was a prevalent human infection before 1800, so that infection per se cannot explain the increased prevalence of the ulcer after this time nor the shift from gastric ulcer to duodenal ulcer (Graham, 2003). Interest in understanding the role of $H$. pylori in gastroduodenal diseases was started in the 1970s with the visualization of bacteria in the stomach of gastric ulcer patients, although the more important researches about it were carry out by the Australian pathologist Berry Marshal in 1979 in collaboration with J Robin Warren from 1981 (Warren JR, 1983). Almost by accident, successful culture of $H$. pylori in 1982 occurred. Marshall frustrated by not being able to get a good animal model of infection, ingested these bacteria and he became ill, developed inflammation and ulcer of stomach, and he was able to culture the bacteria from his own ulcer, proving H. pylori to be the cause of ulcers. They published the results of selfinduced infection in 1985 (Marshall et al., 1985) and initially, the isolated bacteria was termed Campylobacter pyloridis but it was re-named Helicobacter pylori (H. pylori) when biochemical and genetic characterization of the organism showed that it was not a member of the Campylobacter genus (Tan \& Wong, 2011).

\subsection{Morphological and biochemical characteristics}

H. pylori is a spiral-shaped, flagellated, microaerophilic Gram-negative bacillus. It inhabits various areas of stomach and duodenum. Stomach is normally a hostile environment to the survival of viruses, bacteria and other micro-organisms due to its low $\mathrm{pH}$. However $H$. pylori has evolved to be uniquely suited to thrive in the harsh stomach environment (Fig. 1). 
The bacterium secretes urease, a special enzyme that converts urea to ammonia. Ammonia reduces the acidity of stomach, making it more hospitable home for H. pylori (Pandey et al., 2010).

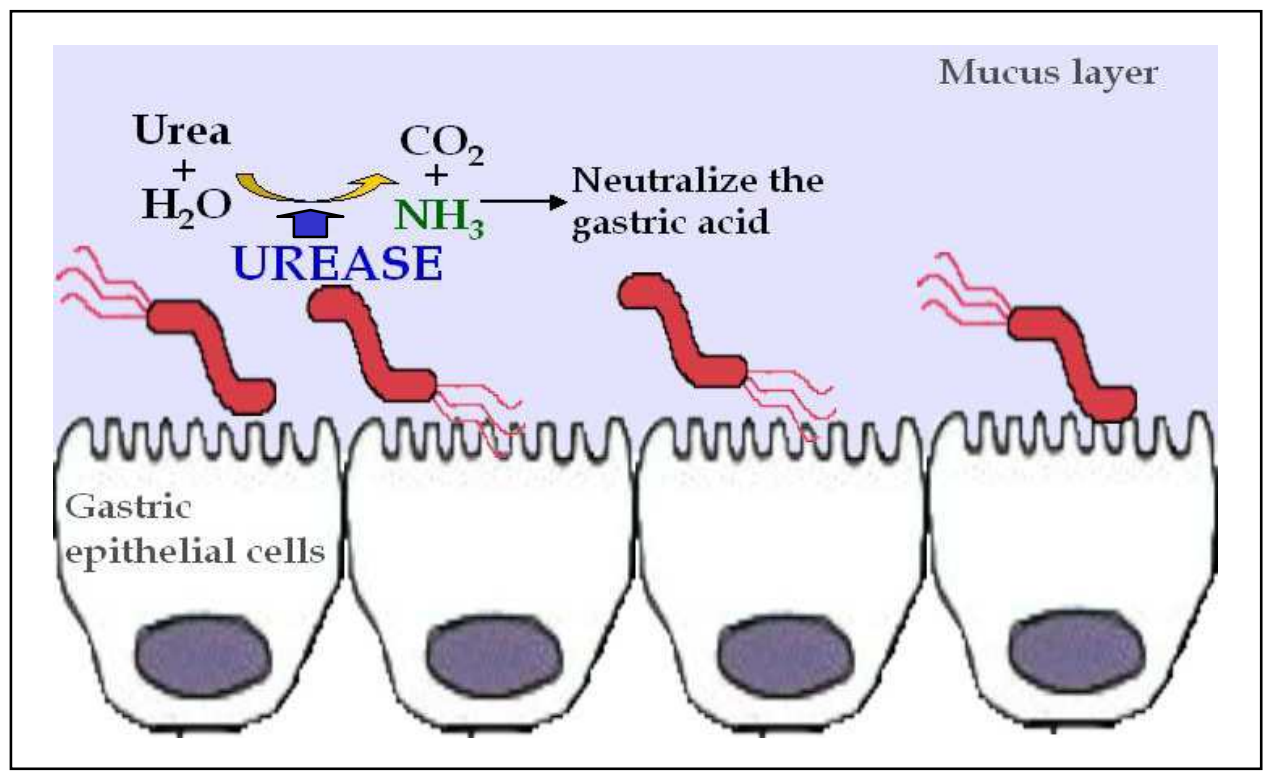

Fig. 1. H. pylori localization in the gastric mucosa and ammonia production.

H. pylori exerts a trophic influence on the gastric epithelium, but before it can attach to the epithelium surface it has first to cross the thick mucus layer by adhering to the mucosal surface. The presence of unipolar flagella helps to establish the H.pylori colonization of the stomach and its attachment to the epithelial surface of mucosa in the stomach despite the host attempts to rid itself of the bacterial infection. It is of interest that mutant $H$. pylori strains that are non-motile are unable to colonize the stomach of gnotobiotic piglets (Eaton et al., 1989).

\subsection{Time, mode and geographic distribution of infection}

H. pylori colonizes the gastric mucosa of more than $50 \%$ of human population. Infection is usually acquired in childhood while natural acquisition in adults is rare. The major risk factor for $H$. pylori infection are the socio-sanitary conditions lived during childhood, particularly at home, being important factors the level of sanitation, hygiene, and number of people in the household (the overcrowding). Studies in Kazakhstan (Nurgalieva et al., 2002) and Peru (Klein et al., 1991), have confirmed that high H. pylori infection prevalence in children in these countries, is related to these factors besides with the use of contaminated water with bacteria. These data determine that the water could be a reservoir and a transmission route for the bacteria.

Moreover, although it has been demonstrated a family association for infection (Nam et al., 2011), the transmission mode of $H$. pylori between individuals and within families remains to be elucidated and several interesting myths related to oral-oral transmission have been 
debunked when a study of couples without children revealed a low concordance of H.pylori infection (Perez-Perez et al., 1991); currently favored mechanisms of transmission appear to be gastro-oral and faecal-oral routes (Xia \& Talley, 1997). Genetic susceptibility also appears to be significant in the acquisition of H.pylori infection as well as its clearance (Malaty et al., 1994).

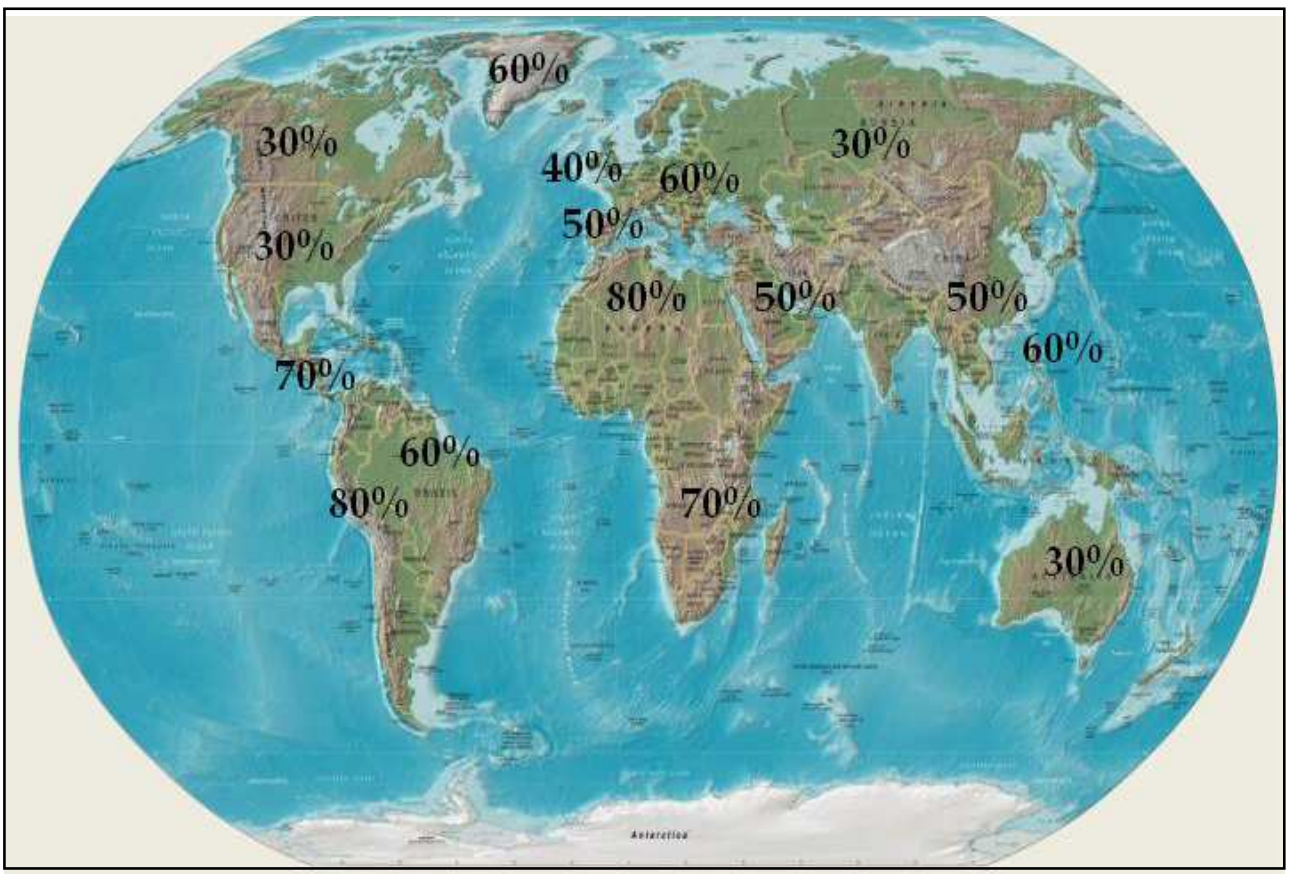

Fig. 2. H. pylori world distribution

Although generally speaking a rate of infection worldwide by about $50 \%$, prevalences varying widely within countries (Fig. 2), and even between geographical areas of the same country (Krejs, 2010). Thus, in developing countries such as the eastern regions of Asia and in some parts of Latin America, the infection prevalence is characterized by a rapid rate of acquisition, usually in childhood, so that about $80 \%$ of the population is infected by the age of 20 (Graham et al., 1991).

In contrast, in developed countries such as Spain, USA, UK or Australia, the prevalence of H. pylori infection in children is low for ages below 10 years, and peaks of $40 \%$ aproximately, occur about to 30-40 years of age (Lehours \& Yilmaz, 2007).

\subsection{General features of Helicobacter pylori infection}

In all infected subjects by $H$. pylori, the basic process that mediates the mucosa damage is the development of gastritis, whose extent and distribution will determine the clinical outcome (Amieva \& El-Omar, 2008).

The arrival of lymphocytes and plasma cells in the mucosa signals augmentation of the acute inflammatory response by the production of cytokines and specific anti- $H$. pylori 


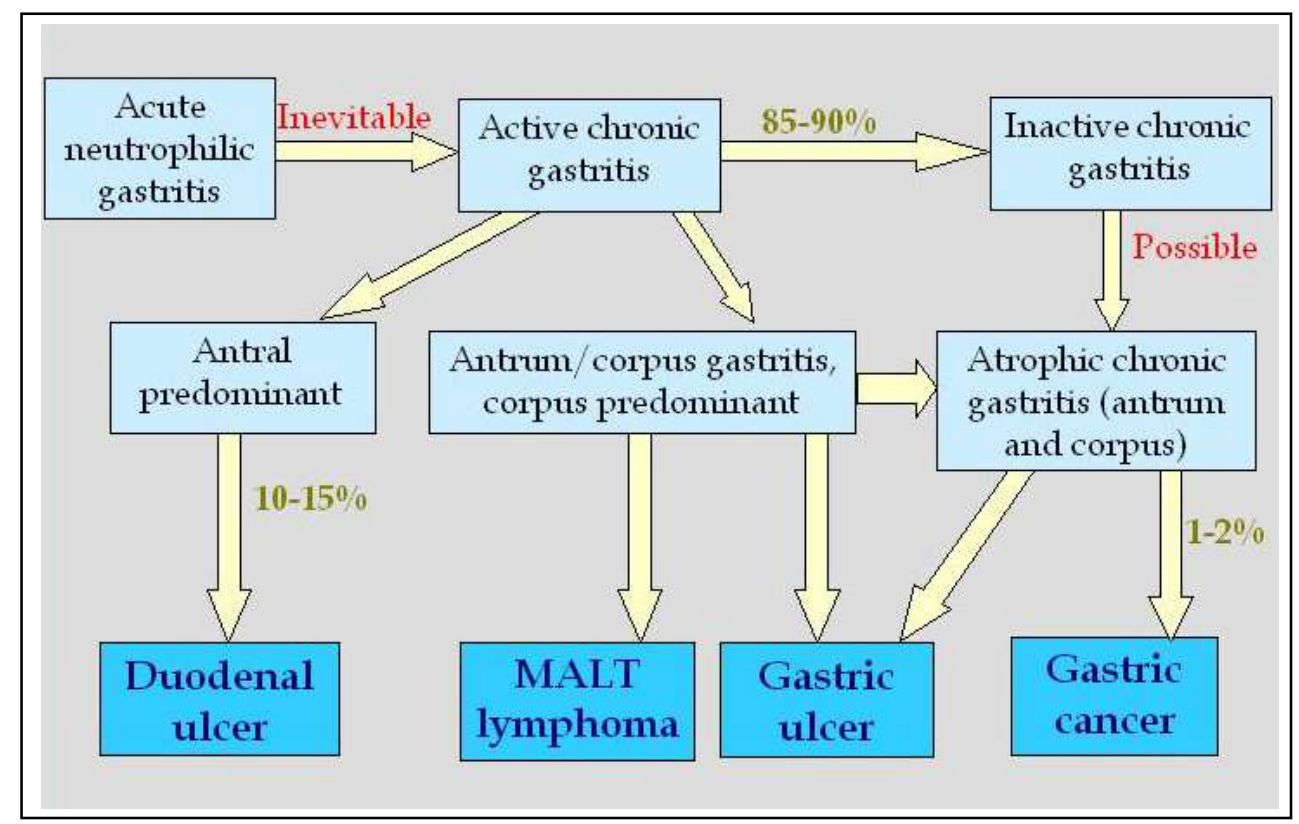

Fig. 3. H. pylori, gastritis and disease. During infection with H. pylori a number of inflammation patterns are associated with different disease stages.

antibodies. However, this vigorous response fails to eliminate infection, and the continued presence of $H$. pylori leads to the development of a second arm of the immune response more specifically aimed at preventing the damaging effects of intraluminal pathogens.

The initial acute phase of infection is subclinical in the great majority of subjects. This phase is short lived, and histologically results in a neutrophilic gastritis followed by a gradual infiltration of the gastric mucosa by inflammatory cells, and is coupled with a transient hypochlorhydria (Egan et al., 2007).

In a small minority of people, and particularly in childhood, the bacteria may be spontaneously cleared, the cellular infiltrate resolves, and the mucosa return to normal appearance. However, in the majority of subjects although $H$. pylori stimulates a robust inflammatory and immune response, the host fails to eliminate the infection and over the next 3 or 4 weeks there is a gradual accumulation of chronic inflammatory cells that come to dominate the histological picture. An acute neutrophilic gastritis gives way to an active chronic gastritis or "bening gastritis" characterized by mild pangastritis with little disruption of gastric acid secretion. This phenotype is exhibited by the asymptomatic subjects and those who do not develop serious gastrointestinal alterations (Amieva \& ElOmar, 2008). In fact, it is commonly accepted that $H$. pylori infection, followed by the induction of inflammatory changes in gastric mucosa, may persist for decades without causing any gastric disturbances (Konturek et al., 2009).

Chronic gastritis is a common denominator linking peptic ulceration, gastric carcinoma, and lymphoma, and the histological picture encompassed chronic inflammation, atrophy, and intestinal metaplasia and finally adenocarcinoma (Dixon, 2001) (Fig. 3). Once chronic gastritis is established, it can progress mainly towards two topographic patterns that are 
related to different clinical outcomes. The first pattern named "duodenal ulcer" phenotype is an antral predominant gastritis, accounts for up 15\% of infected subjects and is characterized by inflammation mostly limited to the antrum. Subjects with this phenotype have high antral inflammatory scores, high gastrin, relatively healthy corpus mucosa, and very high acid output (Graham \& Yamaoka, 1998). These subjects also have defective inhibitory control of gastric acid secretion.

This combination of pathophysiologic abnormalities contributes to the development of peptic ulcers, and confers protection against gastric cancer. Conversely, gastric ulcers are thought to be initially associated with a chronic non-atrophic gastritis which progresses to chronic atrophic gastritis involving both corpus and, invariably, the antrum and decreased acid output.

The second pattern, termed "gastric cancer" phenotype, is one of progressive pan-gastritis or multifocal atrophic gastritis, and hypo- or achlorhydria, characterized by active infection of both the gastric corpus and antrum with progressive development of gastric atrophy and intestinal metaplasia. These abnormalities affect at $1 \%$ of $H$. pylori-infected individuals who presented an increased risk of development gastric carcinoma (Amieva \& El-Omar, 2008).

It is clear that $H$. pylori infection can lead to several divergent clinical outcomes. Explaining this apparent paradox is essential for understanding the pathogenesis of H. pylori-related disease because the mechanisms underlying the differences in outcome of $H$. pylori infection are currently poorly understood. It appears that the host reaction to the infection is very complex and it has been hypothesized that many sequential events and several mechanisms of tissue injury participate in the process. Between these pathogenic mechanisms of $H$. pylori are identified the induction of gastric inflammation, the disruption of the gastric mucosal barrier and the altered gastrin-gastric acid homeostasis (Dunn et al., 1997). Also, these different clinical manifestations of the infection are influenced by the host characteristics, the environmental factors and the bacterial genetic. Host factors are mainly related to the recognition of $H$. pylori by the immune system, variations in the level of cytokine response, sex and hereditary influences. Environmental data include tobacco smoke, diet, stress and the action of drugs such as NSAIDs. Bacterial factors may increase the risk of more severe disease, causing increased proinflammatory cytokine release. Strains possessing the "cag pathogenicity island" are more likely to be associated with peptic ulceration or gastric adenocarcinoma than strains lacking it. Another genes and proteins, such as iceA, vacA, OipA, BabA, have been analyzed but different studies were unable to show an association between them and the pattern of gastritis (Egan et al., 2007).

\subsection{Toxicity of Helicobacter pylori on gastric mucosa (ROS)}

In the early stages of infection, $H$. pylori induces secretion of chemokines (RANTES, GRO $\alpha$, MIP-1 $\alpha$, ENA-78, MCP-1, and IL-8), as well as of proinflammatory cytokines (IL-1, IL-6 and TNF- $\alpha$, mainly) (Ibraghimov \& Pappo, 2000). These molecules provoke recruitment of cells (macrophages, PMN, mast cells, T and B lymphocytes) to the infected gastric tissue, being neutrophils the initial inflammatory component of the response to the pathogen (Naito \& Yoshikawa, 2002). Recruited PMNs, in turn, secrete more inflammatory mediators that amplify the primary signal and mediates directly the influx of more PMN to the gastric mucosa. Furthermore, soluble proteins of $H$. pylori can also function as chemoattractants for neutrophils. PMNs into gastric tissue induce oxidative burst responses in phagocytes being these activities typical in the development of gastric disease. It is demonstrated that H. pylori 
isolates which induce a strong and rapid oxidative burst in neutrophils are associated with higher inflammation scores in gastric ulcer patients and with histological mucosal damage (Louw et al., 1993). Furthermore, IL-8 levels secreted by mucosa cells positively correlate with infiltration of PMN and mononuclear cells, and with higher production of ROS in $H$. pylori-infected antral gastric mucosa (Danese et al., 2001).

ROS production in $H$. pylori infection is catalyzed by nicotinamide adenine dinucleotide phosphate oxidase (NADPH oxidase; Nox) on the cell membrane (Lambeth, 2004). It is also produced superoxide anion $\left(\mathrm{O}_{2}^{-}\right)$, a precursor of microbicidal oxidants. This $\mathrm{O}_{2}^{-}$is converted to hydrogen peroxide $\left(\mathrm{H}_{2} \mathrm{O}_{2}\right)$ by superoxide dismutase (SOD) catalysis, or by nonenzymatic dismutation in the phagosome. $\mathrm{H}_{2} \mathrm{O}_{2}$ can passively permeate cell membranes and is converted to hypochlorous acid $(\mathrm{HOCl})$, which is 100 times more toxic than $\mathrm{H}_{2} \mathrm{O}_{2}$. This conversion is mediated by myeloperoxidases (MPO) released by Azur granules in phagocytes in the presence of chloride ions (Cl-). $\mathrm{H}_{2} \mathrm{O}_{2}$ also reacts nonenzymatically with $\mathrm{O}_{2}-$ to form hydroxyl radicals $\left({ }^{\circ} \mathrm{OH}\right)$ in the presence of ferrous $(\mathrm{Fe} 2+)$ or cuprous $(\mathrm{Cu}+)$ ions. In general, these highly reactive $\mathrm{ROS}$ (i.e., $\mathrm{HOCl}$ and ${ }^{\circ} \mathrm{OH}$ ) are used by the phagocyte to kill pathogenic bacteria (Fig.4).

However, in H. pylori-infected gastric mucosa, these ROS cannot eradicate $H$. pylori and this excessive production is believed to be a major cause of gastric mucosal damage, inducing oxidative stress to the gastric mucosa cells (Handa et al., 2010).

Thus, the role of oxidative stress on gastric mucosa is multi-functional. For neutrophils, it is the result of excessive defense reactions of the body against $H$. pylori intrusion, and for $H$. pylori, it is a convenient tool for invading the human gastric mucosa.

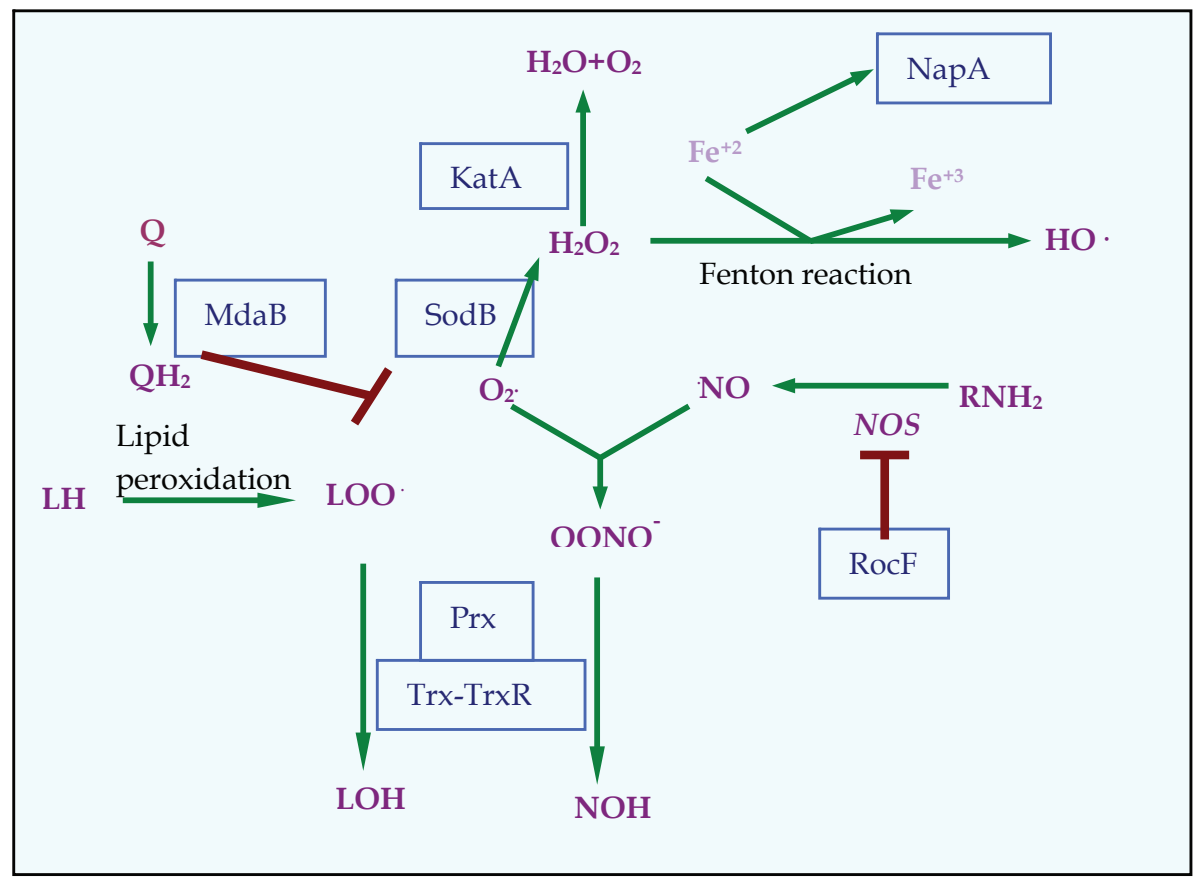

Fig. 4. Sources of ROS and the detoxification systems in H. pylori 
As noted above, some factors that may further aggravate the pathogenicity caused by $H$. pylori are the genetic characteristics of bacteria. In fact, the possession of "cytotoxinassociated gene (cagA) or pathogenicity island" is associated with a high prevalence of peptic ulcer disease. And also, according to the authors Danese et al (Danese et al., 2001) and others, the gastric mucosa of patients infected by CagA (+) strains are characterized by increased ROS generation and neutrophil counts greater than that observed in CagA (-) subjects.

\subsection{Helicobacter pylori, ROS and cellular apoptosis}

Several studies have shown a relationship between $H$. pylori infection and an increased apoptosis rate in gastric lesions such as chronic gastritis, generally accompanied by glandular atrophy, gastric ulcer and intestinal metaplasia. Specifically, studies in patients with gastric ulcer determine a higher apoptotic index in this type of gastric lesion with $H$. pylori infection compared to H. pylori-negative normal gastric mucosa (Targa et al., 2007). Results of Satoh et al (Satoh et al., 2003) showed that apoptosis, not only of surface epithelial cells but also of glandular cells in the upper portion of fundic glands, is increased in $H$. pylori-positive patients with gastric ulcers and decreased to normal levels after eradication of $H$. pylori. Recent studies are intended to avoid triggering apoptotic processes caused by $H$. pylori (Hsu et al., 2010). In these experiments, authors use substances capable of inhibiting the activation of caspase cascade (extract solanum lyratum in this study). This could be a new approach for the treatment of infection with $H$. pylori.

It is known that some of the major stimuli that can induce apoptosis are: ionising radiation, viral infection, growth factor depletion, cytoplasmic stress, serum starvation, presence of hormones such as corticosteroids, the damage to genetic material and an excessive presence of free radical. Given that one of the factors that triggers cellular apoptosis is the excess of ROS, it is reasonable to think that the apoptosis observed in gastric mucosal cells infected by H. pylori may have this origin.

Apoptosis was first described in 1972 by Currie and colleagues (Kerr et al., 1972). It plays a pivotal part in many physiological settings, including the embryonic and post-embryonic development of multicellular organisms, tissue homeostasis and the removal of damaged and/or infected cells. It is delicately regulated and balanced in a physiological context. Failure of this regulation results in pathological conditions such as developmental defects, autoimmune diseases, neurodegeneration or cancer (Thompson, 1995). Apoptosis is by far the best-characterized mode of programmed cell death that is associated to morphological features that had been repeatedly observed in various tissues and cell types. Apoptotic cells display typical morphological features such as nuclear fragmentation, chromatin condensation and cell shrinkage, and eventually break down into apoptotic bodies. These morphological changes are accompanied by ATP-dependent biochemical changes that lead to the cells to various functional alterations. The results of these changes are reflected in an asymmetry of the cytoplasmic membranes by translocation of phosphatidylserine to the surface, breaking of DNA in multiples fragments (ladder pattern), release of pro-apoptotic proteins (cytochrome $\mathrm{c}$ (cyt c), AIF,...) from the mitochondria to cytosol, activation of caspases cascade, and finally, cell death.

Apoptotic cascade appears to have many regulatory "switch points" between proapoptotic and antiapoptotic forces. The imbalance of these forces has led to several key concepts regarding the importance of apoptosis in health and disease. Thus, atrophy of an organ with 
a decrease in cell numbers could be related to an increase in cellular apoptosis, whereas tissue proliferation may be associated with molecular inhibition of apoptosis; in some diseases, internal or external factors could trigger the proapoptotic machinery within the cell causing cell death and tissue destruction; or cellular malignant transformation may occur because of a failure to activate apoptosis and delete cells with genetic damage (i.e., oncogenic mutations). These concepts suggest the possibility that several treatment strategies are useful in certain clinical conditions. Thus, inhibition of apoptosis could facilitate tissue repair processes by promoting cellular proliferation, and tissue regeneration, and, moreover, induction of apoptosis could be proven useful in treating malignant carcinomas (Que \& Gores, 1996).

In relationship with the gastrointestinal tract, apoptosis plays an important role in the regulation of epithelial cell numbers, being the deregulation of the apoptotic pathway implicated in a number of disease processes in the gastrointestine. In H. pylori-induced chronic gastritis, cell loss by apoptosis is excessive compared with proliferation, suggesting that infection with the bacteria triggers the acceleration of apoptosis, fact that has been proven in in vivo experiments (Hall et al., 1994).

Two distinct, but partially overlapping, pathways are known to lead to apoptosis (Fig.5):

- $\quad$ the extrinsic (receptor mediated pathway), and

- the intrinsic (mitochondrial pathway).

The extrinsic pathway is activated by apoptotic stimuli comprising external signals such as the binding of death inducing ligands to cell surface receptors. Among death inducing ligands more studied are Fas, tumor necrosis factor receptor or TRAIL receptors.

Death ligand stimulation results in oligomerization of the receptors and recruitment of the adaptor protein Fas-associated death domain (FADD) and caspase-8, forming a deathinducing signalling complex (DISC). Autoactivation of caspase- 8 at the DISC is followed by activation of effector caspases, including caspase- $3,-6$ and -7 , which function as downstream effectors of the cell death program (Ashkenazi \& Dixit, 1998). Fas has a central role in the physiological regulation of apoptosis and has been implicated in the pathogenesis of various malignancies as well as in diseases of the immune system. Fas is involved in cytotoxic T-cell mediated killing of cells (for example, CTL-mediated killing of virus-infected cells), destruction of inflammatory and immune cells in immune-privileged sites, deletion of selfreacting B cells and activated T-cells at the end of an immune response (Jin \& El-Deiry, 2005).

Some in vitro studies reveal that $H$. pylori stimulates apoptosis of gastric epithelial cells in association with the enhanced expression of the Fas receptor, indicating a role for Fasmediated signaling in the programmed cell death that occurs in response to H. pylori infection (Jones et al., 1999). Wang et al. (Wang et al., 2000) also demonstrated that local Th1 cells (cellular subtype that is mainly recruited to the gastric mucosa during the infection) may contribute to the pathogenesis of gastric disease during $H$. pylori infection by increasing the expression of Fas on gastric epithelial cells and inducing apoptosis through Fas/FasL interactions. Moreover, H. pylori can sensitize human gastric epithelial cells and enhance susceptibility to TRAIL-mediated apoptosis (Wu et al., 2004).

Intrinsic apoptotic pathway is initiated inside cells. The most important turning point in the course of the intrinsic apoptotic process occurs in the mitochondria. Their structure and compartmentalization are highly related to a perfect performance of their functions, being the most relevant, in eukaryotic cells, energy production in ATP form molecules (Chinnery \& Schon, 2003). 


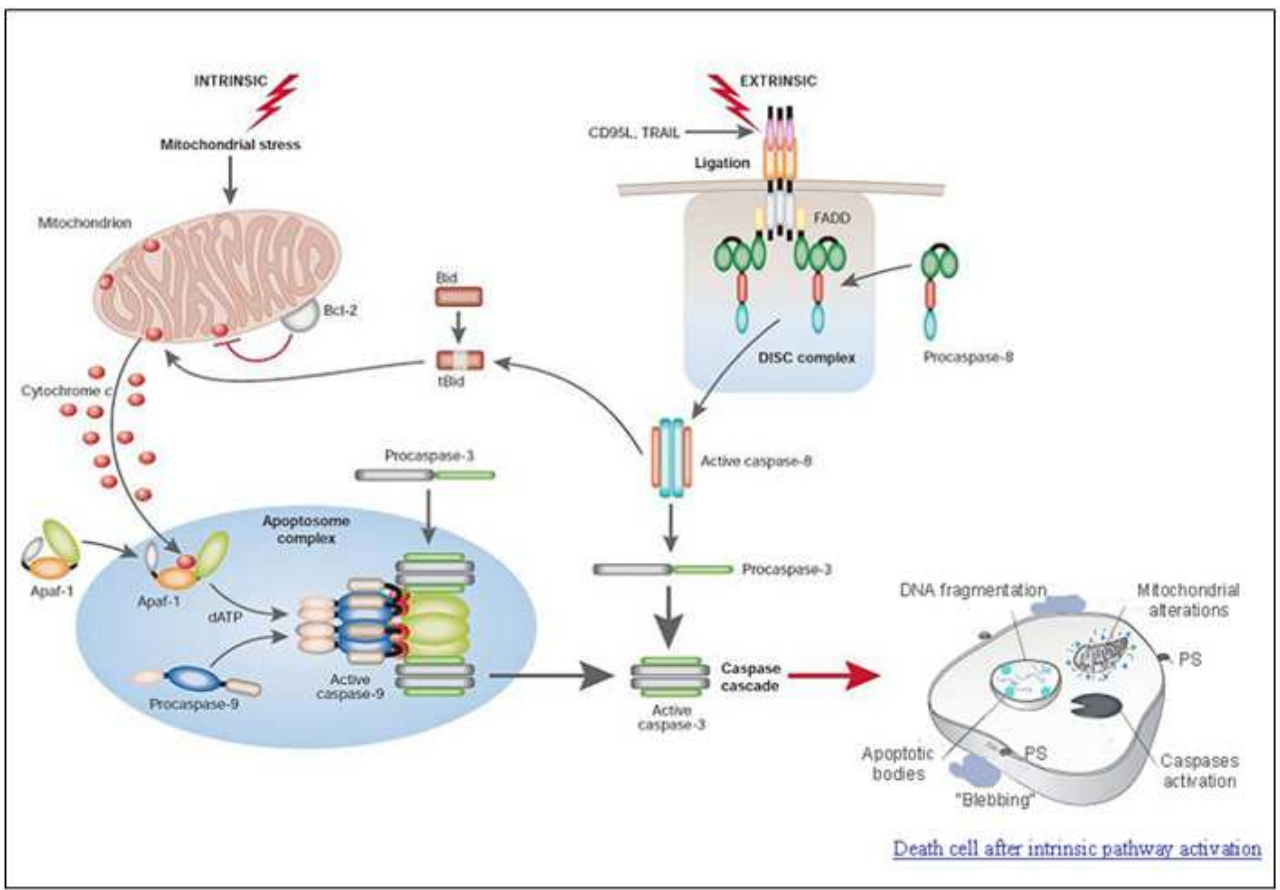

Fig. 5. Apoptotic pathways: the extrinsic pathway involves so-called death receptors, the intrinsic one involves mitochondrial alterations. Both pathways converge at caspase-3 activation, where classic biochemical and morphological changes in association with the apoptotic phenotype are originated

Every mitochondrion has a double lipid envelope that delimites the matrix, located within the inner mitochondrial membrane (IMM) and the intermembrane space located, in turn, between the IMM and the outer mitochondrial membrane (OMM). IMM cristae or invaginations increase the area where specific mitochondrial processes develop (electron transport and oxidative phosphorylation) (Fig. 6). The efficacy of these processes greatly depends on the bilayer's appropriate composition and structure, which relies on the role of the phospholipid cardiolipin (CL). CL is a specific component of IMM and the most abundant in it. On the CL are anchored many proteins such as respiratory chain I-IV complexes and cytochrome c (cyt c) (Calvino Fernandez \& Parra Cid, 2010). Particularly relevant is the electrostatic binding between CL and cyt $\mathrm{c}$ in the IMM since this limits the amounts of cyt $\mathrm{c}$ that can be released during apoptosis (Iverson \& Orrenius, 2004; Ott et al., 2002).

The crucial step in mitochondrion regulated apoptosis is the permeabilization of the OMM, often considered as the "point of no return" in apoptosis signalling (Orrenius et al., 2003), accompanied by the loss of mitochondrial membrane potential $(\Delta \Psi \mathrm{m})$ and mitochondrial transition pores (MTP) opening. OMM permeabilization is followed by the release of caspase activating proteins such as cyt $\mathrm{c}$ and second mitochondrion-derived activator of caspase (SMAC; also known as DIABLO) into the cytosol.

The past 10 years have seen considerable efforts to decipher the molecular pathways leading to permeabilization of the OMM, and it was early recognized that the Bcl-2 family of 


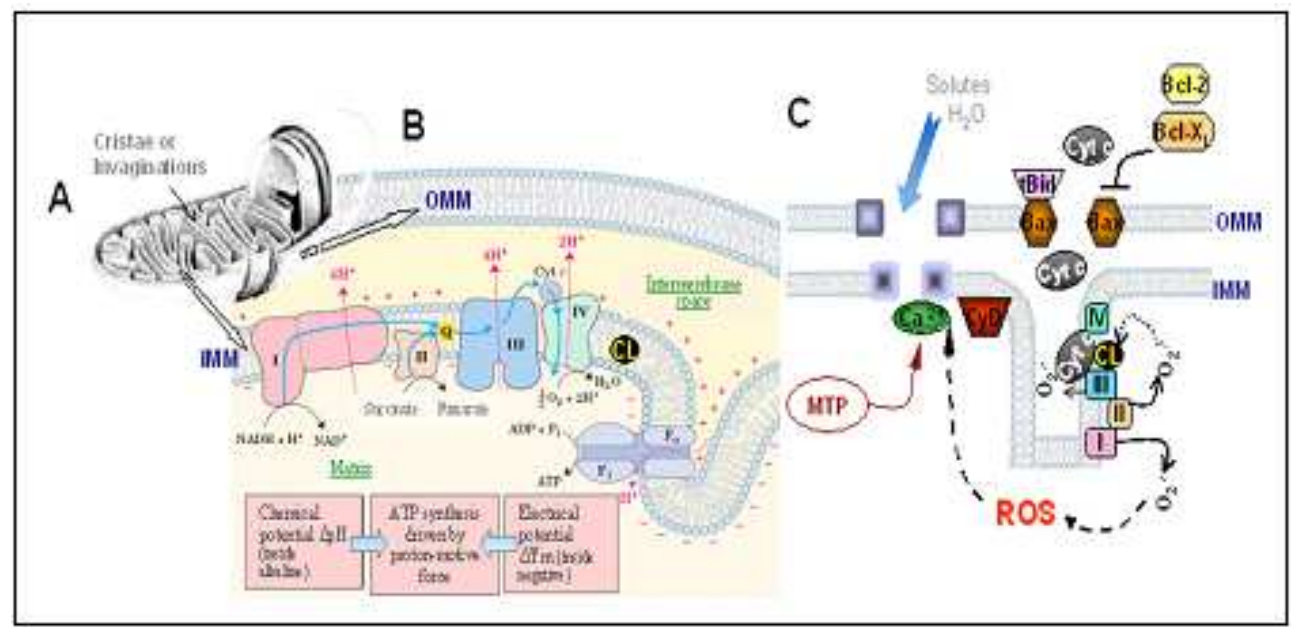

Fig. 6. Mitochondria: structure and function. A) Mitochondrial structure. B) Mitochondrial membranes: relationship between electron transport chain complexes, cytochrome c, and cardiolipin. C) Mitochondrial transition pore formation: ruptured links between protein complexes and cardiolipin, and release of cytochrome c into the cytosol . OMM: outer mitochondrial membrane; IMM: inner mitochondrial membrane; CL: cardiolipin; cyt c: cytochrome c; MTP: mitochondrial transition pores.

proteins play a prominent role in the regulation and execution of this process. As a result of this work, three different types of Bcl-2 family proteins have been identified: (a) the proapoptotic mediators, namely Bax and Bak; (b) the anti-apoptotic effectors, notably Bcl-2, BclXL and Mcl-1; and (c) a host of Bcl-2 homology domain 3 (BH3-only) proteins which control either both the pro- and anti-apoptotic family members or only a specific member of one group (Youle \& Strasser, 2008). The exact mechanisms of action and interplay of all these proteins are still a matter of vibrant debate. But there is general agreement that Bax and Bak are the terminal mediators of OMM permeabilization. As a result of Bax insertion /oligomerization into the OMM (promoted, i.e., by the cleavage of the BH3-only protein, Bid), pores are formed that mediate the release of pro-apoptotic proteins from the intermembrane space into the cytosol. The molecular nature of such pores, that is whether they are proteinaceous or lipidic, is currently not known (Ott et al., 2009).

Recently, apoptosis by mitochondrial pathway in H. pylori infection has been thoroughly studied (Calore et al., 2010; Calvino-Fernandez et al., 2008; Chiozzi et al., 2009; Domanska et al., 2010; Kim et al., 2010; Kim et al., 2007; Matsumoto et al., 2010; Yamasaki et al., 2006; Zhang et al., 2007). Thus, in this research line we can find papers that evidence how VacA, one of the major pathogenic products of $H$. pylori which induces large vacuoles within gastric epithelial cells, stimulates apoptosis via a mitochondria-dependent pathway (Chiozzi et al., 2009; Domanska et al., 2010; Galmiche et al., 2000; Kim et al., 2010). Some authors say that it interferes with mitochondrial permeability and reduces $\Delta \Psi \mathrm{m}$, followed by cyt $\mathrm{c}$ release. It is suggested that VacA may not act directly to induce cyt $\mathrm{c}$ release from mitochondria, instead Bax and Bcl-2 homologous antagonist/killer (Bak), were activated and relocated to mitochondria, promoting cyt c release (Calore et al., 2010; Matsumoto et al., 2010; Yamasaki et al., 2006). 
Not only VacA has been seen to be involved in H. pylori-induced mitochondria pathway apoptosis. Apurinic/apyrimidinic endonuclease-1 (APE-1) regulates transcriptional activity of p53, and H pylori (and ROS) induce APE-1 expression in human gastric epithelial cells, increasing intracellular calcium ion concentration of these cells which induces APE-1 acetylation. This $H$. pylori-mediated acetylation of APE-1 suppresses Bax expression, preventing p53-mediated apoptosis when $H$. pylori infects gastric epithelial cells (Bhattacharyya et al., 2009; Chattopadhyay et al., 2010).

In vivo studies indicate that $H$. pylori-induced apoptosis is associated with an increase in Bak expression in gastric biopsies from patients colonized by the bacterium. Konturek et al. reported induction of apoptosis with evidence of Bax up-regulation and Bcl-2 downregulation in duodenal ulcer patients with $H$. pylori infection (Konturek et al., 1999).

It is known that mitochondria are one of the possible targets and the major intracellular source of free radicals (ROS), since it is estimated that $1-2 \%$ of the oxygen consumed by mitochondria (and they consume $85 \%$ of all body oxygen) in the electron transport chain is converted to $\mathrm{O}_{2}$-- (Shigenaga et al., 1994). Elevated amounts of $\mathrm{O}_{2}$ - $^{-}$could have detrimental effects on nearby molecules, modifying several proteins of the mitochondrial membrane, lipids or even mitochondrial DNA (which has limited protection because of its lack of histones). In physiological conditions, mitochondria have several enzymes (manganesedependent superoxide dismutase, glutathione peroxidase) and non-enzimatic systems (NADPH, Vit $\mathrm{C}$ and $\mathrm{E}$ ) that maintain $\mathrm{O}_{2}-$ - concentrations at very low levels. But when some events cause an overproduction of free radicals, these systems are not able to eliminate the excess. Therefore, overproduction of ROS may also reduce the antioxidant defenses.

This oxidative stress may damage cellular components (Fig. 7), including polyunsaturated fatty acids, carbohydrates, structural and regulatory proteins, and DNA (Baik et al., 1996; Calvino-Fernandez et al., 2008; Jacobson, 1996).

It could well play a role in epithelial proliferation, apoptosis, and oxidative DNA damage. Lipids of cellular membranes, such as CL, are particularly susceptible to oxidation due to the amount of double bonds in their structure, and it is expected that structural changes would be deleterious to normal mitochondrial function (Calvino-Fernandez et al., 2008; Calvino Fernandez \& Parra Cid, 2010).

It is widely known that $H$. pylori infection increases epithelial apoptosis in gastric mucosa, which may play an important role in gastric carcinogenesis (Xia \& Talley, 2001), and $H$. pylori-induced apoptosis may stimulate compensatory hyperproliferation which results in potential preneoplastic changes in chronic H. pylori infection (Moss et al., 1996). Besides, as noted above, higher levels of apoptosis have been detected in ulcer lesions (Satoh et al., 2003; Targa et al., 2007) in patients infected with bacteria, and also, this increased apoptosis disappears when $H$. pylori is eradicated. In both clinical alterations, ulcer and cancer, are also shown that there is an increase of oxidative stress.

With all these data, it is reasonable to assume that whether $H$. pylori causes oxidative stress with an increase of free radicals production, these ROS could directly affect mitochondria and trigger the apoptosis by a similar way shown in Fig.7 (Calvino Fernandez \& Parra Cid, 2010). An indisputable proof that these two processes (ROS and apoptosis) are related to, is the inhibition of apoptosis by treatment with antioxidants. In in vitro experiments (CalvinoFernandez et al., 2008), H. pylori caused apoptosis in gastric epithelial cells. Simultaneously alterations in several structural and functional characteristics of mitochondria (high $\mathrm{O}_{2}$ synthesis, decreased levels of antioxidant enzymes, cardiolipin oxidation, loss of membrane potential, large amounts of cytosolic cit c, higher levels of Bax and caspases,...) were 
detected. All these changes were eliminated by incubating the cells with Vit E during the period of infection. The antioxidant, also prevented that the cells died by apoptosis.

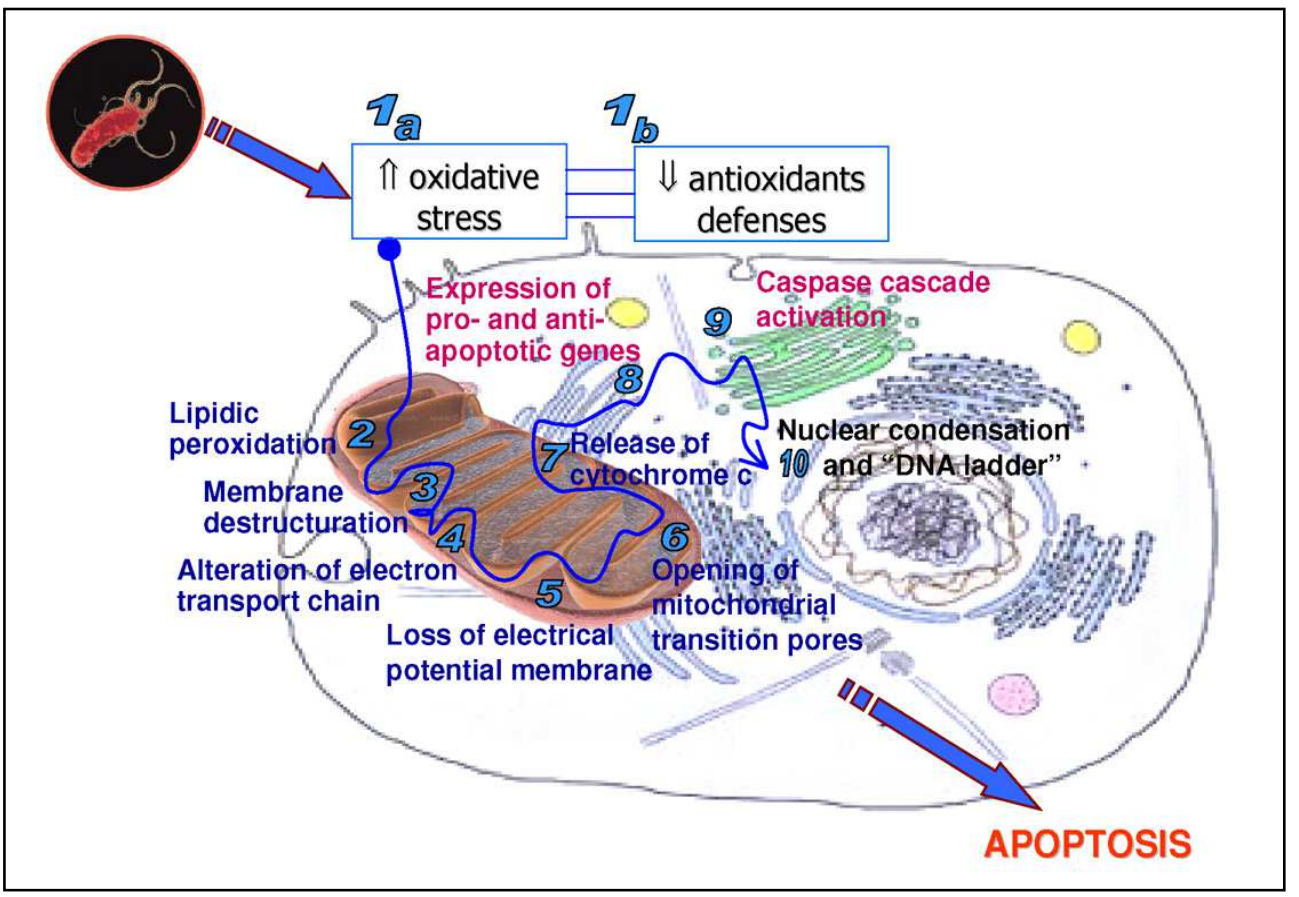

Fig. 7. Morphologic and functional alterations caused by H. pylori in epithelial gastric cells. ROS can directly affect mitochondria and trigger apoptotic process.

Solanum lyratum extract (SLE) was also able to suppress $H$. pylori-induced apoptosis (Hsu et al., 2010). SLE inhibited caspase-8 activation, thereby preventing the release of cyt c from mitochondria and activation of the subsequent downstream apoptotic pathway. Thus, SLE may offer a new approach for the treatment of $H$. pylori by down-regulation of apoptosis in the $H$. pylori infected gastric epithelium. As it does not directly target bacteria, SLE treatment might not cause development of resistant strains.

\section{Conclusions}

General knowledge of scientific advances is necessary not only to read and interpret the literature but also to diagnose and treat diseases appropriately. The biological phenomena contributing to oxidative stress and cell death, fundamental processes in many gastrointestinal diseases, are important in the science and practice of gastroenterology. Currently a scientific revolution is ongoing in the understanding of cell death by a process referred to as "apoptosis or programmed cellular death", and the underlying causes of apoptosis are being the subject of many studies.

H. pylori infection is associated with chronic gastritis, peptic ulcers, and gastric cancer. Extensive scientific evidence shows that in these alterations are involved oxidative stress 
(exacerbated synthesis of ROS) caused by the bacteria by different mechanisms. In addition, a common feature of all these pathologies is the activation of apoptosis, either by extrinsic or, as it is more accepted today, for intrinsic pathway.

Novel therapeutic strategies that may be useful in the prevention or treatment of disorders of the stomach and duodenum caused by bacteria, should have as target the inhibition of the synthesis of ROS and/or apoptosis. Whereas the excess of free radicals is the origin of these alterations, the first step to take would be to restore the balance between oxidants and antioxidant systems. This would eliminate the oxidative stress of the gastric mucosa.

With respect to ROS, the actions may be aimed to the inhibition of its exacerbated synthesis, which serve to mitigate the toxic effects caused by the observed deficiencies in the antioxidant levels. Another strategy could be external supplementation of scavengers to remove this excess of free radicals. The antioxidant vitamins are the logical first choice as therapeutic agents, because of the large amount of data available on their role in $H$. pylori infection, gastroduodenal disease and gastric cancer.

Other new approach for the treatment of $H$. pylori could be the down-regulation of apoptosis in infected gastric epithelium. This might be possible by administering substances that inhibit the activation of caspases. Thus, it would prevent the release of cyt c from mitochondria and as a result, the subsequent downstream apoptotic pathway.

These actions are directed against the toxic manifestations caused by infection, while the traditional treatments with antibiotics have as target the bacterium itself. Consequently, these strategies would also prevent the development of resistant strains, an increasingly common problem due to the usual antibiotic treatments.

\section{Acknowledgment}

This chapter was partly funded by a research grant PI-2008134 of Fundación para la Investigación Sanitaria en Castilla La-Mancha (FISCAM). The work of M. Calvino was funded by Instituto de Salud Carlos III through a "Contrato de Apoyo a la Investigación en el SNS" (CA07/00157).

\section{References}

Amieva, M. R., \& El-Omar, E. M. (2008). Host-bacterial interactions in Helicobacter pylori infection. Gastroenterology, Vol.134, No.1, pp. 306-323, ISSN 1528-0012 (Electronic) 0016-5085 (Linking)

Ashkenazi, A., \& Dixit, V. M. (1998). Death receptors: signaling and modulation. Science, Vol.281, No.5381, pp. 1305-1308, ISSN 0036-8075 (Print) ISSN 0036-8075 (Linking)

Baik, S. C., Youn, H. S., Chung, M. H., Lee, W. K., Cho, M. J., Ko, G. H., Park, C. K., Kasai, H., \& Rhee, K. H. (1996). Increased oxidative DNA damage in Helicobacter pyloriinfected human gastric mucosa. Cancer Res, Vol.56, No.6, pp. 1279-1282, ISSN 00085472 (Print) 0008-5472 (Linking)

Bhattacharyya, A., Chattopadhyay, R., Burnette, B. R., Cross, J. V., Mitra, S., Ernst, P. B., Bhakat, K. K., \& Crowe, S. E. (2009). Acetylation of apurinic/apyrimidinic endonuclease-1 regulates Helicobacter pylori-mediated gastric epithelial cell apoptosis. Gastroenterology, Vol.136, No.7, pp. 2258-2269, ISSN 1528-0012 (Electronic) 0016-5085 (Linking) 
Calore, F., Genisset, C., Casellato, A., Rossato, M., Codolo, G., Esposti, M. D., Scorrano, L., \& de Bernard, M. (2010). Endosome-mitochondria juxtaposition during apoptosis induced by H. pylori VacA. Cell Death Differ, Vol.17, No.11, pp. 1707-1716, ISSN 1476-5403 (Electronic) 1350-9047 (Linking)

Calvino-Fernandez, M., Benito-Martinez, S., \& Parra-Cid, T. (2008). Oxidative stress by Helicobacter pylori causes apoptosis through mitochondrial pathway in gastric epithelial cells. Apoptosis, Vol.13, No.10, pp. 1267-1280, ISSN 1573-675X (Electronic) 1360-8185 (Linking)

Calvino Fernandez, M., \& Parra Cid, T. (2010). H. pylori and mitochondrial changes in epithelial cells. The role of oxidative stress. Rev Esp Enferm Dig, Vol.102, No.1, pp. 41-50, ISSN 1130-0108 (Print) 1130-0108 (Linking)

Chattopadhyay, R., Bhattacharyya, A., \& Crowe, S. E. (2010). Dual regulation by apurinic/apyrimidinic endonuclease-1 inhibits gastric epithelial cell apoptosis during Helicobacter pylori infection. Cancer Res, Vol.70, No.7, pp. 2799-2808, ISSN 1538-7445 (Electronic) 0008-5472 (Linking)

Chinnery, P. F., \& Schon, E. A. (2003). Mitochondria. J Neurol Neurosurg Psychiatry, Vol.74, No.9, pp. 1188-1199, ISSN 0022-3050 (Print) 0022-3050 (Linking)

Chiozzi, V., Mazzini, G., Oldani, A., Sciullo, A., Ventura, U., Romano, M., Boquet, P., \& Ricci, V. (2009). Relationship between Vac A toxin and ammonia in Helicobacter pylori-induced apoptosis in human gastric epithelial cells. J Physiol Pharmacol, Vol.60, No.3, pp. 23-30, ISSN 1899-1505 (Electronic) 0867-5910 (Linking)

Danese, S., Cremonini, F., Armuzzi, A., Candelli, M., Papa, A., Ojetti, V., Pastorelli, A., Di Caro, S., Zannoni, G., De Sole, P., Gasbarrini, G., \& Gasbarrini, A. (2001). Helicobacter pylori CagA-positive strains affect oxygen free radicals generation by gastric mucosa. Scand J Gastroenterol, Vol.36, No.3, pp. 247-250, ISSN 0036-5521 (Print) 0036-5521 (Linking)

Das, D., Bandyopadhyay, D., Bhattacharjee, M., \& Banerjee, R. K. (1997). Hydroxyl radical is the major causative factor in stress-induced gastric ulceration. Free Radic Biol Med, Vol.23, No.1, pp. 8-18, ISSN 0891-5849 (Print) 0891-5849 (Linking)

Davies, G. R., Simmonds, N. J., Stevens, T. R., Sheaff, M. T., Banatvala, N., Laurenson, I. F., Blake, D. R., \& Rampton, D. S. (1994). Helicobacter pylori stimulates antral mucosal reactive oxygen metabolite production in vivo. Gut, Vol.35, No.2, pp. 179-185, ISSN 0017-5749 (Print) 0017-5749 (Linking)

Dixon, M. F. (2001): Pathology of Gastritis and Peptic Ulceration. In M. G. Mobley HLT, Hazell SL (Ed.): Helicobacter pylori: Physiology and Genetics, ASM Press, Washington (DC).

Domanska, G., Motz, C., Meinecke, M., Harsman, A., Papatheodorou, P., Reljic, B., DianLothrop, E. A., Galmiche, A., Kepp, O., Becker, L., Gunnewig, K., Wagner, R., \& Rassow, J. (2010). Helicobacter pylori VacA toxin/subunit p34: targeting of an anion channel to the inner mitochondrial membrane. PLoS Pathog, Vol.6, No.4, pp. e1000878, ISSN 1553-7374 (Electronic) 1553-7366 (Linking)

Dunn, B. E., Cohen, H., \& Blaser, M. J. (1997). Helicobacter pylori. Clin Microbiol Rev, Vol.10, No.4, pp. 720-741, ISSN 0893-8512 (Print) 0893-8512 (Linking)

Eaton, K. A., Morgan, D. R., \& Krakowka, S. (1989). Campylobacter pylori virulence factors in gnotobiotic piglets. Infect Immun, Vol.57, No.4, pp. 1119-1125, ISSN 0019-9567 (Print) 0019-9567 (Linking) 
Egan, B. J., Holmes, K., O'Connor, H. J., \& O'Morain, C. A. (2007). Helicobacter pylori gastritis, the unifying concept for gastric diseases. Helicobacter, Vol.12 Suppl 2, pp. 39-44, ISSN 1083-4389 (Print) 1083-4389 (Linking)

Galmiche, A., Rassow, J., Doye, A., Cagnol, S., Chambard, J. C., Contamin, S., de Thillot, V., Just, I., Ricci, V., Solcia, E., Van Obberghen, E., \& Boquet, P. (2000). The N-terminal $34 \mathrm{kDa}$ fragment of Helicobacter pylori vacuolating cytotoxin targets mitochondria and induces cytochrome c release. EMBO J, Vol.19, No.23, pp. 6361-6370, ISSN 0261-4189 (Print) 0261-4189 (Linking)

Graham, D. Y. (2003). Changing patterns of peptic ulcer, gastro-oesophageal reflux disease and Helicobacter pylori: a unifying hypothesis. Eur J Gastroenterol Hepatol, Vol.15, No.5, pp. 571-572, ISSN 0954-691X (Print) 0954-691X (Linking)

Graham, D. Y., Adam, E., Reddy, G. T., Agarwal, J. P., Agarwal, R., Evans, D. J., Jr., Malaty, H. M., \& Evans, D. G. (1991). Seroepidemiology of Helicobacter pylori infection in India. Comparison of developing and developed countries. Dig Dis Sci, Vol.36, No.8, pp. 1084-1088, ISSN 0163-2116 (Print) 0163-2116 (Linking)

Graham, D. Y., \& Yamaoka, Y. (1998). H. pylori and cagA: relationships with gastric cancer, duodenal ulcer, and reflux esophagitis and its complications. Helicobacter, Vol.3, No.3, pp. 145-151, ISSN 1083-4389 (Print) 1083-4389 (Linking)

Haenszel, W., Correa, P., Lopez, A., Cuello, C., Zarama, G., Zavala, D., \& Fontham, E. (1985). Serum micronutrient levels in relation to gastric pathology. Int J Cancer, Vol.36, No.1, pp. 43-48, ISSN 0020-7136 (Print) 0020-7136 (Linking)

Hall, P. A., Coates, P. J., Ansari, B., \& Hopwood, D. (1994). Regulation of cell number in the mammalian gastrointestinal tract: the importance of apoptosis. J Cell Sci, Vol.107 ( Pt 12), pp. 3569-3577, ISSN 0021-9533 (Print) 0021-9533 (Linking)

Halliwell B, G. J. (1989). Free radicals in biology and Medicine. 2nd edition. Clarendon Press, Oxford), pp. 416

Handa, O., Naito, Y., \& Yoshikawa, T. (2010). Helicobacter pylori: a ROS-inducing bacterial species in the stomach. Inflamm Res, Vol.59, No.12, pp. 997-1003, ISSN 1420-908X (Electronic) 1023-3830 (Linking)

Hsu, Y. M., Lai, C. H., Su, C. H., Kuo, W. W., Kuo, C. L., Hsu, C. K., Wang, C. K., Chang, C. Y., \& Chung, J. G. (2010). Solanum lyratum extract inhibits Helicobacter pylorimediated apoptosis in human gastric epithelial cells. Anticancer Res, Vol.30, No.4, pp. 1189-1193, ISSN 1791-7530 (Electronic) 0250-7005 (Linking)

Ibraghimov, A., \& Pappo, J. (2000). The immune response against Helicobacter pylori--a direct linkage to the development of gastroduodenal disease. Microbes Infect, Vol.2, No.9, pp. 1073-1077, ISSN 1286-4579 (Print) 1286-4579 (Linking)

Iverson, S. L., \& Orrenius, S. (2004). The cardiolipin-cytochrome c interaction and the mitochondrial regulation of apoptosis. Arch Biochem Biophys, Vol.423, No.1, pp. 3746, ISSN 0003-9861 (Print) 0003-9861 (Linking)

Jacobson, M. D. (1996). Reactive oxygen species and programmed cell death. Trends Biochem Sci, Vol.21, No.3, pp. 83-86, ISSN 0968-0004 (Print) 0968-0004 (Linking)

Jaskiewicz, K., Van Helden, P. D., Wiid, I. J., Steenkamp, H. J., \& Van Wyk, M. J. (1990). Chronic atrophic gastritis, gastric $\mathrm{pH}$, nitrites and micronutrient levels in a population at risk for gastric carcinoma. Anticancer Res, Vol.10, No.3, pp. 833-836, ISSN 0250-7005 (Print) 0250-7005 (Linking) 
Jin, Z., \& El-Deiry, W. S. (2005). Overview of cell death signaling pathways. Cancer Biol Ther, Vol.4, No.2, pp. 139-163, ISSN 1538-4047 (Print) 1538-4047 (Linking)

Jones, N. L., Day, A. S., Jennings, H. A., \& Sherman, P. M. (1999). Helicobacter pylori induces gastric epithelial cell apoptosis in association with increased Fas receptor expression. Infect Immun, Vol.67, No.8, pp. 4237-4242, ISSN 0019-9567 (Print) 00199567 (Linking)

Kerr, J. F., Wyllie, A. H., \& Currie, A. R. (1972). Apoptosis: a basic biological phenomenon with wide-ranging implications in tissue kinetics. Br J Cancer, Vol.26, No.4, pp. 239257, ISSN 0007-0920 (Print)

Kim, J. M., Kim, J. S., Lee, J. Y., Sim, Y. S., Kim, Y. J., Oh, Y. K., Yoon, H. J., Kang, J. S., Youn, J., Kim, N., Jung, H. C., \& Kim, S. (2010). Dual effects of Helicobacter pylori vacuolating cytotoxin on human eosinophil apoptosis in early and late periods of stimulation. Eur J Immunol, Vol.40, No.6, pp. 1651-1662, ISSN 1521-4141 (Electronic) 0014-2980 (Linking)

Kim, K. M., Lee, S. G., Park, M. G., Song, J. Y., Kang, H. L., Lee, W. K., Cho, M. J., Rhee, K. H., Youn, H. S., \& Baik, S. C. (2007). Gamma-glutamyltranspeptidase of Helicobacter pylori induces mitochondria-mediated apoptosis in AGS cells. Biochem Biophys Res Commun, Vol.355, No.2, pp. 562-567, ISSN 0006-291X (Print) 0006-291X (Linking)

Klein, P. D., Graham, D. Y., Gaillour, A., Opekun, A. R., \& Smith, E. O. (1991). Water source as risk factor for Helicobacter pylori infection in Peruvian children. Gastrointestinal Physiology Working Group. Lancet, Vol.337, No.8756, pp. 1503-1506, ISSN 01406736 (Print) 0140-6736 (Linking)

Knekt, P., Aromaa, A., Maatela, J., Aaran, R. K., Nikkari, T., Hakama, M., Hakulinen, T., Peto, R., \& Teppo, L. (1991). Vitamin E and cancer prevention. Am J Clin Nutr, Vol.53, No.1 Suppl, pp. 283S-286S, ISSN 0002-9165 (Print) 0002-9165 (Linking)

Konturek, P. C., Konturek, S. J., \& Brzozowski, T. (2009). Helicobacter pylori infection in gastric cancerogenesis. J Physiol Pharmacol, Vol.60, No.3, pp. 3-21, ISSN 1899-1505 (Electronic) 0867-5910 (Linking)

Konturek, P. C., Pierzchalski, P., Konturek, S. J., Meixner, H., Faller, G., Kirchner, T., \& Hahn, E. G. (1999). Helicobacter pylori induces apoptosis in gastric mucosa through an upregulation of Bax expression in humans. Scand J Gastroenterol, Vol.34, No.4, pp. 375-383, ISSN 0036-5521 (Print) 0036-5521 (Linking)

Krejs, G. J. (2010). Gastric cancer: epidemiology and risk factors. Dig Dis, Vol.28, No.4-5, pp. 600-603, ISSN 1421-9875 (Electronic) 0257-2753 (Linking)

Lambeth, J. D. (2004). NOX enzymes and the biology of reactive oxygen. Nat Rev Immunol, Vol.4, No.3, pp. 181-189, ISSN 1474-1733 (Print) 1474-1733 (Linking)

Lehours, P., \& Yilmaz, O. (2007). Epidemiology of Helicobacter pylori infection. Helicobacter, Vol.12 Suppl 1, pp. 1-3, ISSN 1083-4389 (Print) 1083-4389 (Linking)

Louw, J. A., Falck, V., van Rensburg, C., Zak, J., Adams, G., \& Marks, I. N. (1993). Distribution of Helicobacter pylori colonisation and associated gastric inflammatory changes: difference between patients with duodenal and gastric ulcers. J Clin Pathol, Vol.46, No.8, pp. 754-756, ISSN 0021-9746 (Print) 0021-9746 (Linking) 
Malaty, H. M., Engstrand, L., Pedersen, N. L., \& Graham, D. Y. (1994). Helicobacter pylori infection: genetic and environmental influences. A study of twins. Ann Intern Med, Vol.120, No.12, pp. 982-986, ISSN 0003-4819 (Print) 0003-4819 (Linking)

Marotta, R. B., \& Floch, M. H. (1991). Diet and nutrition in ulcer disease. Med Clin North Am, Vol.75, No.4, pp. 967-979, ISSN 0025-7125 (Print) 0025-7125 (Linking)

Marshall, B. J., Armstrong, J. A., McGechie, D. B., \& Glancy, R. J. (1985). Attempt to fulfil Koch's postulates for pyloric Campylobacter. Med J Aust, Vol.142, No.8, pp. 436-439, ISSN 0025-729X (Print)

Matsumoto, A., Isomoto, H., Nakayama, M., Hisatsune, J., Nishi, Y., Nakashima, Y., Matsushima, K., Kurazono, H., Nakao, K., Hirayama, T., \& Kohno, S. (2010). Helicobacter pylori VacA Reduces the Cellular Expression of STAT3 and Prosurvival Bcl-2 Family Proteins, Bcl-2 and Bcl-X(L), Leading to Apoptosis in Gastric Epithelial Cells. Dig Dis Sci, ISSN 1573-2568 (Electronic) 0163-2116 (Linking)

Moss, S. F., Calam, J., Agarwal, B., Wang, S., \& Holt, P. R. (1996). Induction of gastric epithelial apoptosis by Helicobacter pylori. Gut, Vol.38, No.4, pp. 498-501, ISSN 0017-5749 (Print) 0017-5749 (Linking)

Naito, Y., \& Yoshikawa, T. (2002). Molecular and cellular mechanisms involved in Helicobacter pylori-induced inflammation and oxidative stress. Free Radic Biol Med, Vol.33, No.3, pp. 323-336, ISSN 0891-5849 (Print) 0891-5849 (Linking)

Nam, J. H., Choi, I. J., Cho, S. J., Kim, C. G., Lee, J. Y., Nam, S. Y., Park, S. R., Kook, M. C., Nam, B. H., \& Kim, Y. W. (2011). Helicobacter pylori infection and histological changes in siblings of young gastric cancer patients. J Gastroenterol Hepatol, ISSN 1440-1746 (Electronic) 0815-9319 (Linking)

Nurgalieva, Z. Z., Malaty, H. M., Graham, D. Y., Almuchambetova, R., Machmudova, A., Kapsultanova, D., Osato, M. S., Hollinger, F. B., \& Zhangabylov, A. (2002). Helicobacter pylori infection in Kazakhstan: effect of water source and household hygiene. Am J Trop Med Hyg, Vol.67, No.2, pp. 201-206, ISSN 0002-9637 (Print) 00029637 (Linking)

Oh, T. Y., Yeo, M., Han, S. U., Cho, Y. K., Kim, Y. B., Chung, M. H., Kim, Y. S., Cho, S. W., \& Hahm, K. B. (2005). Synergism of Helicobacter pylori infection and stress on the augmentation of gastric mucosal damage and its prevention with alpha-tocopherol. Free Radic Biol Med, Vol.38, No.11, pp. 1447-1457, ISSN 0891-5849 (Print) 0891-5849 (Linking)

Orrenius, S., Zhivotovsky, B., \& Nicotera, P. (2003). Regulation of cell death: the calciumapoptosis link. Nat Rev Mol Cell Biol, Vol.4, No.7, pp. 552-565, ISSN 1471-0072 (Print) 1471-0072 (Linking)

Ott, M., Norberg, E., Zhivotovsky, B., \& Orrenius, S. (2009). Mitochondrial targeting of tBid/Bax: a role for the TOM complex? Cell Death Differ, Vol.16, No.8, pp. 10751082, ISSN 1476-5403 (Electronic) 1350-9047 (Linking)

Ott, M., Robertson, J. D., Gogvadze, V., Zhivotovsky, B., \& Orrenius, S. (2002). Cytochrome c release from mitochondria proceeds by a two-step process. Proc Natl Acad Sci U S A, Vol.99, No.3, pp. 1259-1263, ISSN 0027-8424 (Print) 0027-8424 (Linking)

Pandey, R., Misra, V., Misra, S. P., Dwivedi, M., Kumar, A., \& Tiwari, B. K. (2010). Helicobacter pylori and gastric cancer. Asian Pac J Cancer Prev, Vol.11, No.3, pp. 583-588, ISSN 1513-7368 (Print) 1513-7368 (Linking) 
Peng, Y. C., Hsu, C. L., Tung, C. F., Chou, W. K., Huang, L. R., Hung, D. Z., Hu, W. H., \& Yang, D. Y. (2008). Chemiluminescence assay of mucosal reactive oxygen species in gastric cancer, ulcer and antral mucosa. Hepatogastroenterology, Vol.55, No.82-83, pp. 770-773, ISSN 0172-6390 (Print) 0172-6390 (Linking)

Perez-Perez, G. I., Witkin, S. S., Decker, M. D., \& Blaser, M. J. (1991). Seroprevalence of helicobacter pylori infection in couples. J Clin Microbiol, Vol.29, No.3, pp. 642-644, ISSN 0095-1137 (Print) 0095-1137 (Linking)

Phull, P. S., Green, C. J., \& Jacyna, M. R. (1995). A radical view of the stomach: the role of oxygen-derived free radicals and anti-oxidants in gastroduodenal disease. Eur $\mathrm{J}$ Gastroenterol Hepatol, Vol.7, No.3, pp. 265-274, ISSN 0954-691X (Print) 0954-691X (Linking)

Que, F. G., \& Gores, G. J. (1996). Cell death by apoptosis: basic concepts and disease relevance for the gastroenterologist. Gastroenterology, Vol.110, No.4, pp. 1238-1243, ISSN 0016-5085 (Print) 0016-5085 (Linking)

Reilly, P. M., Schiller, H. J., \& Bulkley, G. B. (1991). Pharmacologic approach to tissue injury mediated by free radicals and other reactive oxygen metabolites. Am J Surg, Vol.161, No.4, pp. 488-503, ISSN 0002-9610 (Print) 0002-9610 (Linking)

Satoh, K., Kawata, H., Tokumaru, K., Kumakura, Y., Ishino, Y., Kawakami, S., Inoue, K., Kojima, T., Satoh, Y., Mutoh, H., Kihira, K., \& Sugano, K. (2003). Change in apoptosis in the gastric surface epithelium and glands after eradication of Helicobacter pylori. Dig Liver Dis, Vol.35, No.2, pp. 78-84, ISSN 1590-8658 (Print) 1590-8658 (Linking)

Shigenaga, M. K., Hagen, T. M., \& Ames, B. N. (1994). Oxidative damage and mitochondrial decay in aging. Proc Natl Acad Sci U S A, Vol.91, No.23, pp. 10771-10778, ISSN 00278424 (Print) 0027-8424 (Linking)

Sonnenberg, A. (2007). Time trends of ulcer mortality in Europe. Gastroenterology, Vol.132, No.7, pp. 2320-2327, ISSN 0016-5085 (Print) 0016-5085 (Linking)

Stahelin, H. B., Gey, K. F., Eichholzer, M., \& Ludin, E. (1991). Beta-carotene and cancer prevention: the Basel Study. Am J Clin Nutr, Vol.53, No.1 Suppl, pp. 265S-269S, ISSN 0002-9165 (Print) 0002-9165 (Linking)

Tamura, T., Yokoyama, T., \& Ohmori, K. (2001). Effects of diacerein on indomethacininduced gastric ulceration. Pharmacology, Vol.63, No.4, pp. 228-233, ISSN 0031-7012 (Print) 0031-7012 (Linking)

Tan, V. P., \& Wong, B. C. (2011). Helicobacter pylori and gastritis: Untangling a complex relationship 27 years on. J Gastroenterol Hepatol, Vol.26 Suppl 1, pp. 42-45, ISSN 1440-1746 (Electronic) 0815-9319 (Linking)

Targa, A. C., Cesar, A. C., Cury, P. M., \& Silva, A. E. (2007). Apoptosis in different gastric lesions and gastric cancer: relationship with Helicobacter pylori, overexpression of p53 and aneuploidy. Genet Mol Res, Vol.6, No.3, pp. 554-565, ISSN 1676-5680 (Electronic) 1676-5680 (Linking)

Thompson, C. B. (1995). Apoptosis in the pathogenesis and treatment of disease. Science, Vol.267, No.5203, pp. 1456-1462, ISSN 0036-8075 (Print) 0036-8075 (Linking)

van den Brandt, P. A., Goldbohm, R. A., van 't Veer, P., Bode, P., Dorant, E., Hermus, R. J., \& Sturmans, F. (1993). A prospective cohort study on toenail selenium levels and risk of gastrointestinal cancer. J Natl Cancer Inst, Vol.85, No.3, pp. 224-229, ISSN 00278874 (Print) 0027-8874 (Linking) 
Wallace, J. L. (1992). Non-steroidal anti-inflammatory drug gastropathy and cytoprotection: pathogenesis and mechanisms re-examined. Scand J Gastroenterol Suppl, Vol.192, pp. 3-8, ISSN 0085-5928 (Print) 0085-5928 (Linking)

Wang, J., Fan, X., Lindholm, C., Bennett, M., O'Connoll, J., Shanahan, F., Brooks, E. G., Reyes, V. E., \& Ernst, P. B. (2000). Helicobacter pylori modulates lymphoepithelial cell interactions leading to epithelial cell damage through Fas/Fas ligand interactions. Infect Immun, Vol.68, No.7, pp. 4303-4311, ISSN 0019-9567 (Print) 00199567 (Linking)

Warren JR, M. B. (1983). Unidentified curved bacilli on gastric epithelium in active chronic gastritis. Lancet, Vol.1, No.8336, pp. 1273-1275, ISSN 0140-6736 (Print) 0140-6736 (Linking)

Wu, Y. Y., Tsai, H. F., Lin, W. C., Chou, A. H., Chen, H. T., Yang, J. C., Hsu, P. I., \& Hsu, P. N. (2004). Helicobacter pylori enhances tumor necrosis factor-related apoptosisinducing ligand-mediated apoptosis in human gastric epithelial cells. World J Gastroenterol, Vol.10, No.16, pp. 2334-2339, ISSN 1007-9327 (Print) 1007-9327 (Linking)

Xia, H. H., \& Talley, N. J. (1997). Natural acquisition and spontaneous elimination of Helicobacter pylori infection: clinical implications. Am J Gastroenterol, Vol.92, No.10, pp. 1780-1787, ISSN 0002-9270 (Print) 0002-9270 (Linking)

Xia, H. H., \& Talley, N. J. (2001). Apoptosis in gastric epithelium induced by Helicobacter pylori infection: implications in gastric carcinogenesis. Am J Gastroenterol, Vol.96, No.1, pp. 16-26, ISSN 0002-9270 (Print) 0002-9270 (Linking)

Yamasaki, E., Wada, A., Kumatori, A., Nakagawa, I., Funao, J., Nakayama, M., Hisatsune, J., Kimura, M., Moss, J., \& Hirayama, T. (2006). Helicobacter pylori vacuolating cytotoxin induces activation of the proapoptotic proteins Bax and Bak, leading to cytochrome c release and cell death, independent of vacuolation. J Biol Chem, Vol.281, No.16, pp. 11250-11259, ISSN 0021-9258 (Print) 0021-9258 (Linking)

Yoshikawa, T., Ueda, S., Naito, Y., Takahashi, S., Oyamada, H., Morita, Y., Yoneta, T., \& Kondo, M. (1989). Role of oxygen-derived free radicals in gastric mucosal injury induced by ischemia or ischemia-reperfusion in rats. Free Radic Res Commun, Vol.7, No.3-6, pp. 285-291, ISSN 8755-0199 (Print) 8755-0199 (Linking)

Youle, R. J., \& Strasser, A. (2008). The BCL-2 protein family: opposing activities that mediate cell death. Nat Rev Mol Cell Biol, Vol.9, No.1, pp. 47-59, ISSN 1471-0080 (Electronic) 1471-0072 (Linking)

Zhang, H., Fang, D. C., Lan, C. H., \& Luo, Y. H. (2007). Helicobacter pylori infection induces apoptosis in gastric cancer cells through the mitochondrial pathway. J Gastroenterol Hepatol, Vol.22, No.7, pp. 1051-1056, ISSN 0815-9319 (Print) 08159319 (Linking) 


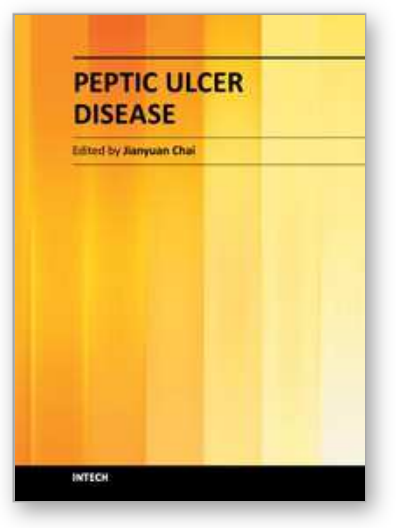

\author{
Peptic Ulcer Disease \\ Edited by Dr. Jianyuan Chai
}

ISBN 978-953-307-976-9

Hard cover, 482 pages

Publisher InTech

Published online 04, November, 2011

Published in print edition November, 2011

Peptic ulcer disease is one of the most common chronic infections in human population. Despite centuries of study, it still troubles a lot of people, especially in the third world countries, and it can lead to other more serious complications such as cancers or even to death sometimes. This book is a snapshot of the current view of peptic ulcer disease. It includes 5 sections and 25 chapters contributed by researchers from 15 countries spread out in Africa, Asia, Europe, North America and South America. It covers the causes of the disease, epidemiology, pathophysiology, molecular-cellular mechanisms, clinical care, and alternative medicine. Each chapter provides a unique view. The book is not only for professionals, but also suitable for regular readers at all levels.

\title{
How to reference
}

In order to correctly reference this scholarly work, feel free to copy and paste the following:

Trinidad Parra-Cid, Miryam Calvino-Fernández and Javier P. Gisbert (2011). Helicobacter pylori and Peptic Ulcer - Role of Reactive Oxygen Species and Apoptosis, Peptic Ulcer Disease, Dr. Jianyuan Chai (Ed.), ISBN: 978-953-307-976-9, InTech, Available from: http://www.intechopen.com/books/peptic-ulcerdisease/helicobacter-pylori-and-peptic-ulcer-role-of-reactive-oxygen-species-and-apoptosis

\section{INTECH}

open science | open minds

\section{InTech Europe}

University Campus STeP Ri Slavka Krautzeka 83/A 51000 Rijeka, Croatia Phone: +385 (51) 770447 Fax: +385 (51) 686166 www.intechopen.com

\author{
InTech China \\ Unit 405, Office Block, Hotel Equatorial Shanghai \\ No.65, Yan An Road (West), Shanghai, 200040, China \\ 中国上海市延安西路65号上海国际贵都大饭店办公楼405单元 \\ Phone: +86-21-62489820 \\ Fax: $+86-21-62489821$
}


(C) 2011 The Author(s). Licensee IntechOpen. This is an open access article distributed under the terms of the Creative Commons Attribution 3.0 License, which permits unrestricted use, distribution, and reproduction in any medium, provided the original work is properly cited. 